\title{
Eerbetoon aan Pieter Fourie
}

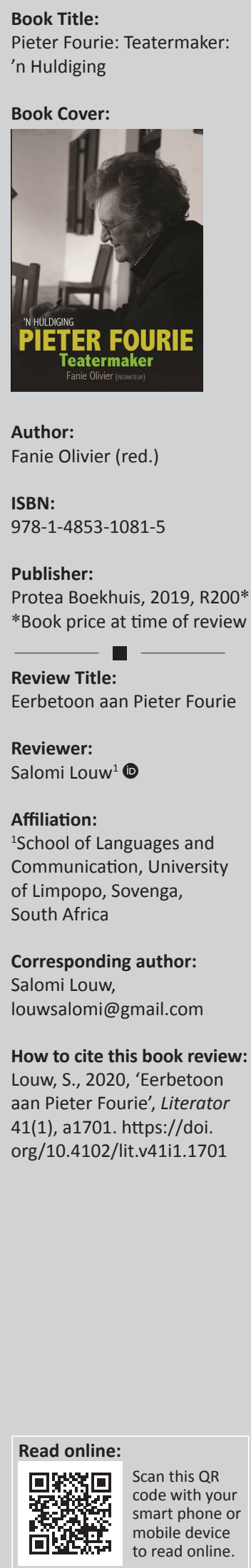

Hierdie eerbewys aan Fourie is gepas, aangesien hy 'n leeftyd gewy het in diens aan die teater en daarvoor erkenning gekry het deur toekennings soos die Herzogprys, die Akademie se Erepenning vir Toneelkuns, die Gerhard Beukes-prys, toekennings deur die Klein Karoo Nasionale Kunstefees (KKNK) en Inniebos Kunstefees, 'n Fleur du Cap-, Fiësta- en Afrikaans Onbeperk-toekenning, en les bes, 'n eredoktorsgraad van die Universiteit van die Vrystaat. Hy verwerf ook NB Vita-toekennings en die Nagtegaal/KKNK-prys. Vir die verwerking van Faan se trein en Faan se stasie tot draaiboek is hy boonop die wenner by die Silwerskermfees in 2013. 'n Gedugte 'teatermaker' dus!

Die inhoud van die huldigingsbundel begin met Daniel Hugo se 'Commendatio vir die Herzogprys vir drama 2003' (of soos op bl. 7: 'Huldigingswoord: Herzogprys vir drama'), waarna Fanie Olivier 'n bondige uiteensetting gee van probleme wat deur die jare ondervind is met die toekenning van die Herzogprys vir drama voordat dit Pieter Fourie te beurt geval het. Olivier kyk ook oorsigtelik na die ander hoofstukke in hierdie publikasie. Hy meld dat daar oorvleueling is tussen die hoofstukke, en dis wel deeglik die geval soos te wagte kan wees waar individuele skrywers afsonderlik oor aspekte skryf waarby dieselfde agtergrond nodig is.

Voor die meer akademiese hoofstukke volg, verskaf Pieter Fourie 'n outobiografiese samevatting: watter lekkerte om só met dié mens, sy werk en sy teatergebondenheid kennis te maak!

Nico Luwes, self 'n teatermaker, het sy doktorsgraad oor Fourie gedoen (2012) en sy proefskrif vorm die grondslag van feitlik al die ander hoofstukke in die bundel;' $n$ hoofstuk uit dié proefskrif word hier as Hoofstuk 3, 'Die stormjare by Kruik', aangebied. Inleidend is daar biografiese inligting van voor Pieter Fourie by Kruik aangestel is. Ons lees van die stryd wat hy gehad het in pogings om dramas op die planke te kry, terwyl die amptenare dit verbied het en van Fourie se afdankings en heraanstellings terwyl hy voortgeveg het om veral die Afrikaanse teater in die Kaap aan die lewe te hou vanaf die einde van 1966 tot 1985. Ook interessant is dit om te verneem van die magdom vertalings wat Fourie gedoen het, om sodoende geskikte toneelopvoerings aan die publiek te kan bied. In 1986 word hy aangestel as inwonende dramaturg by die Transvaalse Raad vir die Uitvoerende Kunste (TRUK) en hier skryf hy van sy sterkste dramas soos Ek, Anna van Wyk en Die koggelaar voor dié pos in 1991 tot 'n einde kom. Na 'n tyd van wêreldreise as deel van die VN se monitorspan vir verkiesings, help hy om die Klein Karoo Nasionale Kunstefees te vestig en van 1994 tot 1999 is hy hier direkteur, waar hy weer eens moet fyntrap oor allerhande probleme by die fees, en moet mooi vra vir befondsing om dié fees aan die lewe te hou; alles met sukses. Luwes lewer deeglik verslag van die navorsing wat hy oor Pieter Fourie, sy lewe en werk gedoen het. Enkele verwarrende feite is egter van die sake wat aan die kwaliteit van hierdie hoofstuk afbreuk doen: Luwes gee die tydperk van die 'Pieter Fourie Toneelgeselskap' aan as 1963-1965 (bl. 48) terwyl dit elders as 1965-1966 aangetoon word (bl. 35, 46, en 105 waar Hauptfleisch dit die 'Pieter Fourie Genootskap' noem). Die tweede dwars feit vertel dat Fourie se 'eerste Faan-stuk eers in 1975, ná publikasie, aan Kruik' voorgelê is (bl. 64), maar op bladsy 67 skryf Luwes dat 'n skaarste aan opvoerbare tekste by Kruik Fourie genoop het om Faan se trein in heroorweging te neem: 'Fourie haal die teks toe uit die laai en lê dit voor'. Op bladsy 52, voetnoot 5, noem Luwes dat Kita Redelinghuys vanaf 1962 vir TRUK gespeel het; TRUK het egter eers in 1963 beslag gekry. Die hoofstuk is wel 'n stewige bydrae. Dis net jammer dat dit basies nét so uit die proefskrif gelig is, sonder bywerking, buiten die verwysing na die twee digbundels; hy praat van Kanna hy kô hystoe wat 'steeds nie opgevoer' is nie (bl. 57), sonder om 'n aanpassing te maak vir wat ná 2012 - die datum van die proefskrif - gebeur het. Van Fourie se dramas wat na 2012 lewe gekry het, word vlugtig in hoofstuk 11, ook deur Luwes bekyk. Ek vind dit egter jammer dat dié bespreking nie by Hoofstuk 3 geïnkorporeer is nie.

Twee bekende koerantresensente, te wete Paul Boekkooi en Kerneels Breytenbach, gee hulle indrukke van Fourie as mens en van sy werk. Boekkooi se bydrae veral is deeglik, helder en goed geformuleer; in 'n kort bestek neem hy die leser deur Fourie se tyd by Kruik, TRUK, 
sy betrokkenheid by Kampustoneel en die KKNK, tot by die draaiboek van Faan se trein. Temple Hauptfleisch lewer 'n esoteriese Hoofstuk 5, waarin hy die seismologie van teater op Fourie se werk toepas. Hy doen dit onder die opskrif: 'Die Dobermann in die hoenderhok ...', wat seker sy weergawe is van die Engelse idioom: 'A bull in a china shop'. Hy wys daarop dat Fourie die stelsel voortdurend uitgedaag en getoets het. Ongelukkig noem Hauptfleisch Die verminktes (Bartho Smit - SL) as een voorbeeld van 'n 'kontroversiële politieke stuk' (bl. 109) waarin Fourie die 'grammatika' van die teater bemeester het.

Hierop volg hoofstukke waarin Fransjohan Pretorius na die biografiese en sosio-politieke agtergrond van Pieter Fourie se dramas kyk; Maritha Snyman gee 'n uiteensetting van die begrip 'kinderdrama' en ondersoek dan Fourie se drie kinderdramas aan die hand hiervan, en kyk ook na hulle volksdramatiese en klugtige aard. In Hoofstuk 8 lewer Thys Human 'n stewige akademiese bespreking onder die opskrif: 'Metadramatiese elemente in Pieter Fourie se vierluik plaastragedies'. $\mathrm{Na}$ 'n verduideliking van dié term pas hy dit toe op Ek, Anna van Wyk, Die koggelaar, Donderdag se mense en Post mortem.

Hoofstuk 9, deur Annebelle Smit, dra die titel, 'Pieter Fourie se komiese werk', wat uiteraard van oorvleueling met ander hoofstukke getuig. Sy wil 'Pieter Fourie se slag met komedie in Die proponentjie (1987), Vat hom, Flaffie! (ook bekend as Hups in die hydro; 1989), Tienuur maak die deure oop (1987) en Daan se doilie (1990) analiseer' (bl. 182). Sy begin egter haar betoog met ' $n$ oorsig van wat 'n aantal skrywers te sê het oor verskillende voorkomste van 'komedie', sonder om tot sintese te kom oor wat haar eie uitgangpunt is. Sy stel dit dat sy ' $[i] n$ hierdie artikel ... die komedies ... analiseer na aanleiding van die mate waarin hulle voldoen aan die vereistes van 'n "volwaardige komedie" ...' (bl. 185). Dan klits sy die terme klug, satiriese komedie, 'n speelse stuk, seksklug en boereklug (bl. 190), sosiale satire (bl. 194), satire (bl. 197), en komedie van gedrag (bl. 202) deurmekaar. Haar analises van Fourie se 'komedies' is gangbaar, maar die styl is soms wollerig, met teenstrydighede soos 'die sukses van ... Vat hom, Flaffie!' (bl. 190) teenoor Weideman se uitspraak 'dat die toneelstuk beslis nie die moeite werd is om te lees of te gaan kyk nie' (bl. 199); en dat die dramaturg 'objektief na die werklikheid' kyk (bl. 184) teenoor: hy is 'uit die aard van die saak eensydig' (bl. 185). Hierdie hoofstuk kon 'n goeie stuk werk gewees het, maar dit lewer heelwat probleme op - wat opgelos kon gewees het indien 'n mentor of redakteur oor haar skouer geloer het.

Marisa Keuris lewer in Hoofstuk 10 'n akademies bevredigende bydrae onder die opskrif, 'Die siekrit van Pieter Fourie se Faan', en Joan Hambidge se 'Kanonisering en herkanonisering - Die poësie van Pieter Fourie binne so 'n konteks' verteenwoordig ' $\mathrm{n}$ insiggewende benadering tot Fourie se digbundels en is myns insiens die mees verdienstelike hoofstuk in hierdie huldigingsbundel.

'n Omvattende bronnelys van werk deur of oor Pieter Fourie, saamgestel deur Burgert Senekal, word verskaf. Hier sou ek ook graag 'n lys wou sien van teatertekste deur die dramaturg vertaal, wat tot opvoering gebring is.

Ten spyte van 'n redakteur wat die finale verantwoordelikheid vir die publikasie moet dra én 'n proefleser wat by die naam erkenning kry, is dié bundel ongelukkig ontsier deur talle seten feitefoute. Sitate word lukraak en eiesoortig aangewend, bibliografiese gegewens kan teenstrydig wees of word nie altyd verskaf nie, en die gebruik van datums van die dramas se eerste opvoering en dan weer die publikasiedatums as verwysing is verwarrend. 'n Mens (spesifiek hierdie resensent) lees later teësinnig, omdat soveel dinge te kort skiet. Ten spyte van hierdie voorbehoude, dink ek tog die gewone teaterganger, kunsteliefhebber en leser sal genot en kennis put uit die eer wat hier aan hierdie 'teatermaker' betoon word. 